Pharmaceuticals, Inc. These data have been submitted to the 2019 APLAR-ARA and SER meetings.

Disclosure of Interests: Gerd Rüdiger Burmester Consultant for: Roche, Sanofi-Genzyme, Speakers bureau: Roche, Sanofi-Genzyme, Howard Amital Grant/research support from: Pfizer, AbbVie, Janssen, Grant/research support from: Pfizer, AbbVie, Janssen, Consultant for: Pfizer, Merck Sharp \& Dohme, Consultant for: Pfizer, Merck Sharp \& Dohme, Speakers bureau: Pfizer, Merck Sharp \& Dohme, Janssen, Sanofi, Bristol-Myers Squibb, Abbvie, Neopharm, Speakers bureau: Pfizer, Merck Sharp \& Dohme, Janssen, Sanofi, Bristol-Myers Squibb, Abbvie, Neopharm, Andrea Rubbert-Roth Consultant for: Chugai, Eli Lilly, Roche, and Sanofi, Speakers bureau: AbbVie, Bristol-Myers Squibb, Chugai, Hexal/Novartis, Janssen, Eli Lilly, Merck Sharp \& Dohme, Pfizer, Roche, and Sanofi, Hubert van Hoogstraten Shareholder of: Sanofi, Regeneron, Novartis, Grant/ research support from: Zambon, Employee of: Sanofi, Leon M. Gervitz Shareholder of: Sanofi, Union Chimique Belge, Abbvie, Celgene, Amgen, Employee of: Sanofi, Karthinathan Thangavelu Shareholder of: Sanofi, Employee of: Sanofi, Gregory St John Shareholder of: Regeneron Pharmaceuticals Inc, Employee of: Regeneron Pharmaceuticals Inc, Mark C. Genovese Grant/research support from: Sanofi/Genzyme, Genentech/ Roche, RPharm, Consultant for: Sanofi/Genzyme, Genentech/Roche, RPharm

DOI: 10.1136/annrheumdis-2019-eular.4646

\section{SAT0138 PREDICTORS OF CLINICAL EFFICACY OF ABATACEPT IN RHEUMATOID ARTHRITIS: DATA FROM A LARGE OBSERVATIONAL STUDY}

Giovanni Cagnotto $^{1,2}$, Minna Willim ${ }^{3}$, Lennart Jacobsson ${ }^{4}$, Michele Compagno ${ }^{2,5}$, Saedis Saevarsdottir ${ }^{6}$, Carl Turesson ${ }^{1,7}$. ${ }^{1}$ Lund University, Clinical Sciences Malmö, Malmö, Sweden; ${ }^{2}$ Skåne University Hospital, Rheumatology, Lund, Sweden; ${ }^{1}$ Lund University, Clinical Sciences Malmö, Malmö, Sweden;

${ }^{4}$ Gothenburg University, Rheumatology and Inflammation Research, Sahlgrenska Academy, Gothenburg, Sweden; ${ }^{5}$ Lund University, Clinical Sciences Lund, Lund, Sweden; ${ }^{6}$ Karolinska Institutet, Stockholm, Sweden; ' Skåne University Hospital, Rheumatology, Malmö, Sweden

Background: Abatacept (ABA) is a biologic DMARD (bDMARD) used to treat rheumatoid arthritis (RA) since 2006. There are limited data on real life efficacy of $A B A$, and on predictors for $A B A$ treatment response.

Objectives: Objectives: To compare the effectiveness of $A B A$ in the treatment of RA between bionaïve patients and patients with previous bDMARDs and to investigate predictors of clinical response to ABA.

Methods: In an observational cohort study, based on data from a large national quality register database, patients with RA diagnosis who initiated treatment with ABA between April 2006 and November 2017 were included. LUNDEX corrected response was defined as the fractions remaining on the drug and achieving the outcome among all who initiated treatment (1). Clinical response at 6 and 12 months was evaluated by means of LUNDEX corrected EULAR (L-EULAR) Good Response and LUNDEX corrected HAQ response (change of $\geq 0.3$ from baseline) (L$H A Q)$. Predictors for clinical response were investigated using logistic regression, with significance based backwards selection of variables for the final multivariate model. The study was supported by an unrestricted grant from Bristol Myers-Squibb.

Results: 2716 RA patients were included in the study. More patients in the bionaïve population achieved L-EULAR Good Response and L-HAQ response at 6 and 12 months than bDMARDs experienced patients (Fig. 1a and 1b). Male sex, no previous bDMARD exposure and a low HAQ score were independent predictors of L-EULAR Good Response at 6 and 12 months (Table 1). Lack of previous bDMARD exposure also predicted $\mathrm{L}-\mathrm{HAQ}$ response at 6 and 12 months. There was a positive associations between baseline $\mathrm{HAQ}$ and $\mathrm{L}-\mathrm{HAQ}$ response at 6 months (multivariate adjusted odds ratio $1.73 ; 95 \% \mathrm{Cl} 1.46-2.05)$.
Conclusion: In patients with RA, response rates for treatment with abatacept were substantially higher in bionaïve patients than in those with previous bDMARD experience. Male sex also predicted LUNDEX corrected EULAR good response to abatacept. Patients with extensive disability, measured by $H A Q$, were less likely to remain on treatment and achieve a EULAR Good Response, but more likely to have significant $\mathrm{HAQ}$ improvement.

\section{REFERENCE}

[1] Kristensen, et al. Arthritis Rheum. 2006;54(2):600-6.

Table 1. Significant predictors of Lundex EULAR good response. Bivariate and adjusted analysis. Odds ratios $(95 \% \mathrm{Cl})$.

\begin{tabular}{|c|c|c|c|c|}
\hline \multirow[b]{2}{*}{ Predictors } & \multicolumn{2}{|c|}{6 months } & \multicolumn{2}{|c|}{12 months } \\
\hline & Bivariate & Multivariate & Bivariate & Multivariate \\
\hline Male sex & $\begin{array}{l}2.11(1.41- \\
\quad 3.13)\end{array}$ & $\begin{array}{l}2.28(1.45- \\
3.57)\end{array}$ & $\begin{array}{l}2.46(1.71- \\
3.54)\end{array}$ & $\begin{array}{l}2.14(1.44- \\
3.19)\end{array}$ \\
\hline $\begin{array}{l}\text { Bionaive (Reference: } \geq 2 \\
\text { bDMARDs) }\end{array}$ & $\begin{array}{l}4.00(2.60- \\
\quad 6.15)\end{array}$ & $\begin{array}{l}3.59(2.25- \\
5.72)\end{array}$ & $\begin{array}{l}4.45(2.95- \\
\quad 6.71)\end{array}$ & $\begin{array}{l}4.29(2.77- \\
6.65)\end{array}$ \\
\hline Current Methotrexate & * & $* *$ & $\begin{array}{c}1.46(1.04- \\
2.06)\end{array}$ & ** \\
\hline HAQ score (per SD) & $\begin{array}{l}0.64(0.52- \\
0.77)\end{array}$ & $\begin{array}{l}0.75(0.61- \\
0.93)\end{array}$ & $\begin{array}{l}0.65(0.54- \\
0.78)\end{array}$ & $\begin{array}{l}0.74(0.61- \\
0.90)\end{array}$ \\
\hline Disease duration (per SD) & $\begin{array}{c}0.79(0.65- \\
0.96)\end{array}$ & $* *$ & $\begin{array}{c}0.72(0.59- \\
0.87)\end{array}$ & $\star \star$ \\
\hline Age (per SD) & $\begin{array}{c}0.76(0.65- \\
0.91)\end{array}$ & $\begin{array}{l}0.79(0.65- \\
0.96)\end{array}$ & * & ** \\
\hline Current Glucocorticoids & $\begin{array}{l}0.59(0.42- \\
0.83)\end{array}$ & $\begin{array}{l}0.59(0.40- \\
0.86)\end{array}$ & * & ** \\
\hline $\begin{array}{l}\text { Intravenous ABA (Reference: } \\
\text { Subcutaneous) }\end{array}$ & $\begin{array}{l}0.53(0.38- \\
0.75)\end{array}$ & $\star *$ & $\begin{array}{l}0.70(0.51- \\
0.98)\end{array}$ & ** \\
\hline
\end{tabular}

${ }^{*}=$ not significant for this outcome

${ }^{* *}=$ not included in the final model.

A

Lundex corrected EULAR good response.

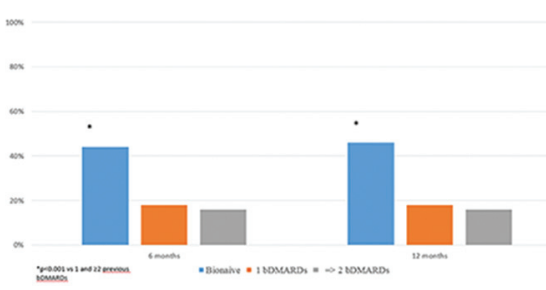

B

Lundex corrected $H A Q$ response

$\sin$

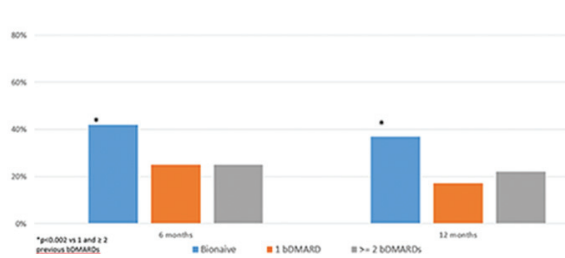

Disclosure of Interests: Giovanni Cagnotto Consultant for: Novartis, less than 3000 Euro, Minna Willim: None declared, Lennart Jacobsson Consultant for: Eli-Lily, Janssen, Novartis, Pfizer, Speakers bureau: Abbvie., Michele Compagno: None declared, Saedis Saevarsdottir Employee of: Part-time employee at deCODE Genetics/Amgen Inc, working on genetic research unrelated to this project., Carl Turesson: None declared DOI: 10.1136/annrheumdis-2019-eular.348 